\title{
TRANSLATION OF OCCASIONAL INNOVATIONS IN ENGLISH LITERARY DISCOURSE
}

S. Shulik, Student

Sumy State University

2, Rymskogo-Korsakova St., Sumy, 40007, Ukraine

E-mail: juliakatz@ukr.net

The work is executed under the direction of Y. Kats,

$\mathrm{PhD}$ in Philology, Associate Professor, Sumy State University

\begin{abstract}
The article deals with the study of occasional innovations in English literary discourse and ways of their translation. It was found out that literary texts are the richest sources of occasional innovations. The conducted research defines the features of functioning of occasionalisms, their inseparability from the context, existence in speech in a certain speech situation, restriction of further spread. The ways of occasional innovations coining were determined, as well as the reasons of their creation.

In the article the main ways of translation of occasional innovations were investigated and also factors influencing their transfer from one language to another.

Key words: occasional innovations, English literary discourse, methods of translation, word-formation derivation.
\end{abstract}

https://doi.org/10.21272/Ftrk.2018.10(3)-07

The society is always in motion as well as the language. Lexis is constantly changing, new words appear and are being coined, old words are revived. At various times language looks different. The most clearly we can observe the processes of this change in the texts of literary discourse.

The painter of the word perceives the world in its own way and seeks how to express its vision of the surrounding reality more precisely, vividly. It is not always possible to implement with the help of ordinary linguistic means, as a result of which new words appear.. Thus, there is a more fresh look at the familiar things.

Despite a significant number of scientific papers, an interest to the study of occasional innovations is growing every day. It is stipulated by the fact that occasionalism coining is a continuous process that requires thorough consideration.

A lot of Ukrainian and Russian linguists, namely: N. H. Babenko, M. A. Bakina, H. A. Vinokur, O. A. Habinska, L. B. Hatsalova, V. S. Himpelevich, L.I. Ploshikova and others focus their research interest on occasionalisms studies.

The relevance of the chosen topic is defined by the necessity to analyze occasional innovations in the English literary discourse and the peculiarities of their translation.

The aim of the article is to study the peculiarities of occasional innovations in English literary discourse and the ways of their translation.

This aim implies the following tasks of the research:

1) to give definition to such notions as discourse, literary discourse, occasionalism;

2) to determine the functions of occasionalisms and their typology, to trace the connection between the value of occasionalisms and the context;

3) to analyze models of the creation of occasionalisms;

4) to find out the main methods of translating ocasional innovations.

The subject area of this study is occasional innovations, that are actualized in the studied texts. The specific topic of the study is English literary texts.

Determination of discourse is unclear, so this notion is used together with such terms as "language" ( "discourse" - "language immersed in life"), "text", "functional style". Discourse (French. discours, Eng. discourse, from Latin. discursus "running back and forth, movement, cycle, conversation, talk") is the process of speech activity, way of speaking. This term has many meanings and is used in a number of sciences, the object of which

(C) S. Shulik, 2018

«Філологічні трактати», Том 10, № 3 ' 2018 
directly or indirectly involves the study of language functioning, that is linguistics, literary criticism, semiotics, sociology, philosophy, anthropology and ethnology [5, p. 220].

Three main features of the discourse were emphasized: 1) in formal way - a unit of language that exceeds the volume of the sentence, 2) in the content of the plan, discourse is associated with the use of language in the social context, 3 ) in its organization discourse is interactive, that is, dialogic.

An important feature of a discourse is the concept dynamics, that gradually unfolds over time. The theme of discourse is its content, which is concentrated around the so-called reference concept. The theme largely relates to the social world, feelings of the speaker, his inner life and problems. Discourse analysis aims to show who controls the themes and their changes (semantic macrostructures), who determines the form and style of speech $[3$, p. 78].

Due to the fact that the main purpose of literary discourse is emotional-volitional and aesthetic influence on those to whom it is addressed, the main factor is its pragmatic essence. The functioning of literary discourse is impossible outside dialectical relations: writer - literary work - reader.

Literary discourse is the interaction between the writer and the reader, an attempt to change the spiritual space of a person and cause a certain emotional reaction, and draws into its sphere cultural, aesthetic, social values, knowledge of the world and the relation to reality, encyclopedic knowledge, system beliefs, ideas and feelings. Literary discourse is the embodiment of a verbal message that transmits subject-logical, aesthetic, figurative, emotional and evaluative information, united in the ideological and artistic content of the text into a single whole [6, p. 178].

An occasional innovation, that could be a word, phrases, sound combinations, syntactic compound, is something that does not correspond to the generally accepted usage, it characterizes an individual creativity, aspiration for unique self-expression and is stipulated by a specific usage context. Occasional innovations are usually inseparable from the context. It is necessary to distinguish occasionalisms from neologisms. Occasionalisms are created in language or speech in a given situation and do not extend further, neologisms are coined to name a new object or phenomenon and are meant for enriching the lexical system of the language [1, p. 78].

Three ways of occasional innovations coining are known:

1) word-formation derivation - formation of new words from the existing in language morphemes through known (usually productive) models; the most common methods of formation of occasionalisms are suffixation, prefixation, prefixation-suffixation, stemcomposition, and often in combination with suffixation, stem truncation (inverse derivation), fusion and conversion;

2) semantic derivation - the process of appearance of semantic derivative meanings, co-meanings, semantic connotations;

3) borrowings from other languages or subsystems of the language - from dialects, vernacular, slang $[9$, p. 200].

An example of compounding, as a way of creating occasionalisms, can be Voldemort, where the French phrase voldemort (flight of death) is united in the whole, Xenophilius Lovegood - in the name are united such Greek stems as xenos - strange and phile - love, but also here the method of affixation is used and the suffix of Latin origin - $u s$ is added, which characterizes the hero as the person who loves strange speeches, Neville Longbottom - here stems long and bottom are united, that means that the person is not too clever, Godric Gryffindor - in this occasionalism the English word griffin and the French $d$ 'ore gold are united, Expelliarmus - here are the English stems expel and arm with the addition of the Latin suffix -us, Merpeople - word has two stems: French mer - sea and British people [18].

The main law of occasionalisms formation is the law of analogy. Most of occasional words are formed according to the analogy with the existing ones. The novelty of occasionalisms is achieved by creation of a new word that is synonymous to a well-known 
one used in the language, which has the same root, but differs from it due to wordformation means, used in a new word [12, p. 78].

Depending on the way of occasionalisms appearance we can distinguish phonetic, lexical, semantic and grammatical occasionalisms.

An occasional innovation is one of the potent means of achieving expressiveness in English literary discourse, as its function is to make a deep impact on an addressee.

In her novel, Zedi Smith very often used created by her words - individual author's neologisms, that are not recorded in any lexicographic source, that attract attention to the original form, making reading the novel, together with other stylistic techniques and means an interesting, unforgettable "journey" in time and in the space, that causes an ironic smile, sincere smile and laugh by the reader.

For example "Straight hair. Straight straight long black sleek flickable, tossable, shakable touchable finger-through-able wind-blowable hair" [21].

In this sentence it is talking about a black teenage girl whose cherished dream is long straight hair instead of natural curls. Neologisms are finger-through-able and windblowable created by compounding and affixation. The humorous effect is created by the obfuscation of the suffixal morpheme -able, that is repeated in all adjectives used to describe the "desired" hair. The morpheme of adjectives, repeated many times, also gives the sentence a certain rhythm, which enhances the emotional effect of describing the impatience of the heroine.

Because of their individual-authorial affiliation, occasionalisms do not have and cannot have "ready" correspondences in another language. For the theory of translation, the occasional word is of great interest precisely because it requires certain cognitive efforts from the translator and non-standard translation solution. Next, we describe the stages of the process of translational of occasionalisms. When translating it is necessary to convey all the shades of meaning that the author wanted to convey to the reader, introducing into this text a particular reality [13, p. 78].

There are a number of means how to translate occasional words. These means were formed in the process of interlanguage contacts: transcription, transliteration, descriptive equivalents, calque, the creation own occasional words by the translator, or the reproduction of occasionalism, omission, the provision to existing words a new meaning. The choice of method depends on the translated word, its derivation, the way of formation.

The methods of transcription and transliteration often found in the novel by John Rowling "Harry Potter": quidditch, squat, squig, squig, and many others [18].

Transcription and transliteration are also used in the novel by Terry Pratchett "Moving Pictures": How does the monster Tshup Aklathep, Infernal Star Toad with a Million Young, torture its victims to death? Яким тортурам чудовисько Шуп Аклапет, Інфернальна Зоряна Жаба з Мільйоном Жабят зазвичай піддає свої жертви? [20].

L. K. Latyshev observes that calque is characterized by a high degree of "mechanistic", and what about the degree of disclosure of the phenomenon described by this method, it depends on how the internal form of the nonequivalent vocabulary reflects its value [14, p. 79].

Proceeding from this, we can make a conclusion that when creating a calque it is important to take into account the formal component of the word, as well as the way in which the original occasionalism was created.

Many examples of the usage of calque technique can be found in the translation of George Orwell's novel "1984":

Blackwhite - білочорний,

Thoughtcrime - думкозлочин,

Thoughtcriminal - думкозлочинець,

Telescreen - телекран (замість існуючого в украӥнській мові слова «телеекран» вводиться оказіоналізм),

Unperson - неособистість,

Memory hole - гніздо пам'яті, 
Thought Police - полічія думки,

Doublethink - дводумка,

Oldthink-cтародумеиьь [17].

Although the word-coinage equivalents "suffer" from literalism, conciseness and potential terminology make them attractive for translators.

The method of omission does not carry expressiveness, as occasionalisms simply throw out. This is why translators try to avoid this method.

But translators of J. Joyce's novel "Ulysses" used this method to convey the content of text that contains occasionalisms. These words were omitted: whowhat, bubblyjocular, buybull, sackragman, bloodwart, alrightness [19].

During translating the literary work from one language to another, we must also take into account those tasks of artistic expression, that are solved by writers through occasionalism.

Conclusion: like all new phenomena, occasionalisms attract the reader's attention, influence a recipient's subconsciousness. They are the response to changes in all key spheres, namely in: society, politics, culture, sports, etc. All these spheres of life are directly reflected in the language.

Only a competent translator will be able to translate occasional innovations accurately. The complexity of the translation process lies in the fact that the translator deals with not only one content, but with a few contents, that are more subjective than objective. When translating occasional innovations it is very important to find out the exact meaning of a particular word, and its absence in the dictionaries is not an obstacle for translation. In addition, the practice of translation makes the largest contribution to the replenishment of vocabulary of the language.

The prospects of the research we see in thorough study of occasional innovations in the advertising or Internet discourse.

\section{ПЕРЕКЛАД ОКАЗІОНАЛЬНИХ ІННОВАЩЙ}

\section{В АНГЛОМОВНОМУ ХУДОЖНЬОМУ ДИСКУРСІ}

С. М. Шулік, студентка

Сумський державний університет,

вул. Римського-Корсакова, 2, Суми, 40007, Украӥна

Робота виконана під керівництвом Ю. В. Кац, канд. філол. наук Сумський державний університет

Стаття присвячена вивченню оказіональних інновачій в англомовному художньому дискурсі та способів їх перекладу. 3'ясовано, шо тексти художнього дискурсу є одними з найбагатших джерел оказіональних інновацій. Під час проведеного дослідження було визначено особливості функціонування оказіоналізмів, ̈̈х нероздільність $з$ контекстом, існування в мові в певній мовленнєвій ситуації, обмеженість поширення. Було визначено способи утворення оказіональних інновачій, причини їх появи. У статті досліджено основні способи перекладу оказіональних інновацій та фактори, щуо впливають на передачу їх з однієї мови на іншу. Перекладаџький аналіз оказіональних інновачій побудовано на методологічній основі, яку утворюють поняття стратегії та способу перекладу. 3 иією метою стратегіi перекладу оказіоналізмів було розподілено на одомашнююючі, відчуюсуючі (горизонтальний вимір), макростратегії, тобто ті, шо діють відносно тексту в иілому, та мікростратегії, тобто ті, що діють відносно окремого елементу або групи елементів (вертикальний вимір). Застосування стратегіі одомашнення проявляється у використанні способів калькування та вибору автохтонного відповідника. Відбір компонентів для створення украӥнського відповідника здійснювався на основі семантичного аналізу вихідної одиниці коштом вивчення ї̈ морфемної структури та широкого контексту. Перспективою подальшого дослідження є вивчення особливостей формування та перекладу оказіональних одинииь інших номінативних иарин. Характерними рисами актуалізації нового слова є: соціальна потреба, часовий чинник, наявність твория, прикріпленість до контексту, наявність мовної моделі й комунікативної цінності. Саме завдяки змінам мова залишається вічно живою та функціональною, а люди образно переосмислюють свій досвід та реалізують зміни повсякденного мовлення

Ключові слова: оказіональні інновачії, англомовний художній дискурс, способи перекладу, словотворча деривація. 


\section{ПЕРЕВОД ОККАЗИОНАЛЬНЫХ ИННОВАЦИЙ В АНГЛОЯЗЫЧНОМ ХУДОЖЕСТВЕННОМ ДИСКУРСЕ}

С. М. Шулик, студентка

Сумский государственный университет,

Римского-Корсакова, 2, г. Сумы, 40007, Украина

Работа выполнена под руководством Ю.В. Кац, канд. филол. наук, Сумский государственный университет

Статья посвящена изучению окказиональных инноваций в англоязычном художественном дискурсе и способов их перевода. Было выяснено, что тексты художественного дискурса являются одними из самых богатых источников окказиональных инноваций. В прочессе исследования были определены особенности функиионирования окказионализмов, их неотделимость от контекста, сушествование в речи в данной речевой ситуации, ограниченность дальнейшего использования. Были определены способы образования окказиональных инноваций, причины их появления.

Также в статье исследованы основные способы перевода окказиональных инноваций и факторы, влияюшие на передачу их с одного языка на другой.

Ключевые слова: окказиональные инновачии, англоязычный художественный дискурс, способы перевода, словообразовательная деривация.

\section{REFERENCES}

1. Azarova L. E. (1998). Occasional nouns, formed by the method of compounding, in the poetic speech by L. Martynov. Russian philology: Ukr.vestnik. Kharkiv, p. 3-7.

2. Babenko N. G. (1997). Occasional in the literary text. Structural-semantic analysis: Textbook. Kaliningrad, 56 p.

3. Baranov A. N. (2001). Introduction to Applied Linguistics. Moscow: Editorial URSS, 2001. 360 p.

4. Barhudarov L. S. (1975). Language and Translation (General and Private Translation Theory Questions). Moscow: International relations, $350 \mathrm{c}$.

5. Bordbotko V. G. (2006). Principles of the formation of discourse: From psycholinguistics to linguistics Moscow: KomKniga, 288 p.

6. Wittgenstein L. (1995). Tractatus Logico-Philosophicus; Philosophical studies. Kyiv.: Fundamentals, 311 p.

7. Hausenblas K. (1978). About the characterization and classification of linguistic works. New in foreign linguistics. K. Hausenblas. Moscow: Progress, p. 57 - 78.

8. Gnatyuk, A. D. (1984).Means of creation the expression and its intensification in newspaper-magazine genres (based on the material of the modern press). Kiev, $199 \mathrm{p}$.

9. Goncharova T. Y., Bilan A. V. (2010). Occasional word and context. Collection of scientific works of the Military Institute of the Kyiv National Taras Shevchenko University. Kyiv, pp. 199 - 206.

10. Zemskaya, E. A. (1995). Language as a mirror of the present (word-formation notes). Philological collection (to the 100th anniversary of the birth of academician V. V. Vinogradov). Moscow: Institution of Russian Language RAH, pp. 154 - 163.

11. Zernetska O. V. (1993). New means of mass communication. Kyiv, pp. 140 - 152

12. Komissarov V. N. (1990). Theory of translation (linguistic aspects): Textbook for institutions and faculties of foreign languages. Moscow: Vyssh. Shk., $253 \mathrm{p}$.

13. Kopylenko O. L. (1991). The power of information . Kyiv, $108 \mathrm{p}$.

14. Latyshev L. K. (2001). Technology of translation. Training manual for the preparation of translators (with German language). Moscow: NVI-Thesaurus, $279 \mathrm{p}$

15. Lopatin V. V. (2001). Birth of the word: neologisms and occasional formations. Moscow, 2001. $152 \mathrm{p.}$

16. Lykov A. G. (2001). Contemporary Russian lexicology (Russian Occasional Word). Moscow, $198 \mathrm{p}$.

17. George Orwell "1984". - URL: https://ebooks.adelaide.edu.au/o/orwell/george/o79n/contents.html.

18. Joanne Rowling "Harry Potter And the Philosopher's Stone". URL https://www.readanybook.com/ebook/harry-potter-and-the-philosophers-stone-565431.

19. Joyce James "Ulysses". - URL: http://www.gutenberg.org/ebooks/4300.

20. Terry Pratchett. Moving Pictures. - URL: https://www.goodreads.com/book/show/34510.Moving_Pictures.

21. Zadie Smith. White Teeth. - URL: https://www.goodreads.com/book/show/3711.White_Teeth.

\section{СПИСОК ВИКОРИСТАНИХ ДЖЕРЕЛ}

1. Азарова Л. Е. Окказиональные имена существительные, образованные способом сложения, в поэтической речи Л. Мартынова // Русская филология: Укр. вестник / Л. Е. Азарова. - Харьков, 1998. C. 3-7.

2. Бабенко Н. Г. Окказиональное в художественном тексте. Структурно-семантический анализ: учебное пособие / Н. Г. Бабенко. - Калининград, 1997. - 56 с.

3. Баранов А. Н. Введение в прикладную лингвистику / А. Н. Баранов. - М. : Едиториал УРСС, 2001. $360 \mathrm{c}$.

4. Бархударов Л. С. Язык и перевод (Вопросы обшей и частной теории перевода) / Л. С. Бархударов. М.: Международные отношения, 1975. - 350 с. 
5. Борботько В. Г. Принципи формування дискурсу: Від психолінгвістики до лінгвосинергетика / В. Г. Борботько. - М. : КомКніга, 2006. - 288 с.

6. Вітгенштайн Л. Tractatus Logico-Philosophicus; Філософські дослідження. - К. : Основи, 1995. - 311 с.

7. Гаусенблас К. Про характеристику та класифікації мовних творів // Нове в зарубіжній лінгвістиці.- М.: Прогрес, 1978. - Вып. 8. - С. 57 - 78.

8. Гнатюк А. Д. Средства создания экспрессии и её интенсификация в газетно-журнальных жанрах (на материале современной прессы) / А. Д. Гнатюк. - Киев, 1984. - 199 с.

9. Гончарова Т. С. Оказіональне слово і контекст // Збірник наукових праць Військового інституту Київського національного університету імені Тараса Шевченка. / Т. Є. Гончарова, А. В. Білан. - К., 2010. - С. 199-206.

10. Земская Е. А. Язык как зеркало современности (словообразовательные заметки) / Е. А. Земская // Филологический сборник (к 100-летию со дня рождения акад. В.В. Виноградова) / отв. ред. М. В. Ляпон. - М.: Ин-т рус. яз. РАН, 1995. - С. 154 - 163.

11. Зернецька О. В. Нові засоби масової комунікації. / О. В. Зернецька. - К., 1993. - С. 140-152.

12. Комиссаров В.Н. Теория перевода (лингвистические аспекты): Учеб. для ин-тов и фак. иностр. яз. В.Н. Комиссаров. - М.: Высш. шк., 1990. - 253 с.

13. Копиленко О. Л. Влада інформації / О. Л. Копиленко. - К., 1991. - 108 с.

14. Латышев Л. К. Технология перевода. Учебное пособие по подготовке переводчиков (с немецким языком) / Л. К. Латышев. - М.: НВИ-Тезаурус, 2001. - 279 с.

15. Лопатин В. В. Рождение слова: неологизмы и окказиональные образования / В. В. Лопатин. M., 2001. - 152 c.

16. Лыков А. Г. Современная русская лексикология (русское окказиональное слово) / А. Г. Лыков. M., 2001. -198 c.

17. George https://ebooks.adelaide.edu.au/o/orwell/george/o79n/contents.html

18. Joanne Rowling "Harry Potter And the Philosopher's Stone" [Електронний pecypc]. - URL: https://www.readanybook.com/ebook/harry-potter-and-the-philosophers-stone-565431.

19. Joyce James "Ulysses" [Електронний ресурc]. - Режим доступу : http://www.gutenberg.org/ebooks/4300.

20. Terry Pratchett "Moving Pictures" [Електронний pecypc]. - URL https://www.goodreads.com/book/show/34510.Moving_Pictures.

21. Zadie Smith "White Teeth" [Електронний pecypc]. - URL: https://www.goodreads.com/book/show/3711.White_Teeth.

Received: 20 January, 2018 